\title{
Competence-building in foreign subsidiaries: The case of new EU member states
}

\author{
Sergey Filippov, Geert Duysters ${ }^{* *}$
}

This article examines patterns of competence-building in foreign subsidiaries located in new member states of the European Union. Among the theoretical foundations of this paper are the concepts of dynamic capabilities and subsidiary-specific advantages. We consider subsidiary competences as a combination of distinctive competences built into particular business functions. Furthermore, we examine sources of competences, and complementarities between these sources. We use a proprietary database to examine the research topic and find distinctive uneven growth of functional competences over time, distinctive patterns of complementarities between different functional competences and specific patterns of access to sources of competence. Finally, we discuss managerial and policy implications.

Dieser Artikel untersucht Muster des Kompetenzaufbaus in ausländischen Niederlassungen, welche in den neuen Mitgliedsstaaten der europäischen Union angesiedelt sind. Das theoretische Fundament dieses Papers bilden die Konzepte der dynamischen Fähigkeiten und niederlassungsspezifischen Vorteile. Wir betrachten das Wissen der Niederlassung als eine Kombination von unterschiedlichen Fähigkeiten die zu speziellen wirtschaftlichen Funktionen kombiniert werden. Des Weiteren untersuchen wir die Quellen von Kompetenzen und Abhängigkeiten zwischen diesen. Wir benutzen eine unternehmenseigene Datenbank um das Forschungsthema zu untersuchen und ausgeprägt unregelmäßiges Wachstum von funktionalen Kompetenzen über die Zeit, markante Muster von Abhängigkeiten zwischen verschiedenen funktionellen Kompetenzen und spezifische Zugangsmodelle zu Kompetenzquellen zu finden. Schließlich diskutieren wir betriebliche und politische Auswirkungen.

Key words: subsidiaries, multinational, competences, capabilities, subsidiary evolution

* Manuscript received: 04.03.2011, accepted 30.07.2011 (1 revision)

** Sergey Filippov, Dr., Assistant Professor of Innovation Management, Delft University of Technology. Main research areas: Innovation, international business, emerging markets, transition economies and emerging multinational companies. Corresponding address: s.filippov@tudelft.nl

Geert Duysters, Prof. Dr., Professor of Entrepreneurship Tilburg University and Eindhoven University of Technology. Main research areas: International business strategies, innovation strategies and strategic alliances 


\section{Introduction}

Recent academic and business literature has provided ample empirical evidence of the significance of intangible assets to the success and competitiveness of firms, which are viewed as a collection of activities, skills and capabilities that are enhanced in a learning process. This also holds true for subsidiaries of multinational companies. Increasing interest in the enhancement of their business (and core) competences can be considered from two sides: (1) from the managerial side, i.e. subsidiary management itself, management of the parent company, parts of the corporate network (management of sister subsidiaries); (2) from the side of the host economy actors, since subsidiaries with higher levels of competence have a higher potential for spillovers and positive externalities for the national host economy.

Traditionally, research into the competences of firms (and subsidiaries in particular) has been conducted within the context of the advanced economies of Northern America and Western Europe. The ground-breaking development of Central and Eastern Europe (CEE) since 1990, specifically within the context of EU membership, naturally calls for a need to investigate the concept of competence in this particular setting, which is why this paper examines the patterns of competence formation in relation to the internal and external characteristics of subsidiaries in new EU member states, using a proprietary database in order to analyse this research subject empirically.

The paper is organised as follows. In the first two sections, we discuss the context of the study and introduce new EU member states. Section 3 provides a literature review and, on the basis of theoretical insights and the context of the study, research questions are formulated in Section 4. Section 5 presents and analysis of the data. Finally, managerial and policy implications are discussed in Section 6.

\section{Context setting: new EU member states}

After (re-)gaining independence in 1989-1991, CEE countries turned from a command socialist-style economy to a market economy. The accession of eight CEE countries to the European Union in 2004 (followed by Bulgaria and Romania in 2007) can be considered a final step in this transition. The dominant agenda of economic transition was based on the 'Washington consensus' neoliberal ideology. Stabilisation, transformation and restructuring became the key words of the economic policies carried out in CEE countries in the 1990s, which included the liberalisation of prices, the liberalisation of foreign trade, the liberalisation of inflow and outflow of foreign capital, large-scale privatisation and the creation of a viable banking and financial system.

New CEE markets became important FDI host economies, especially in the second half of the 1990s. FDI promotion was coupled with economic transition, 
and inward FDI was seen as a major source of gross fixed capital formation. Opening the CEE markets predictably attracted the attention of leading western multinational companies. Several factors, such as new rapidly growing consumer markets, cheap highly-skilled labour and a geographical proximity to Western Europe, strong manufacturing traditions and the legacy of the socialist science and technology base have had a strong impact on the corporate strategies, making these countries attractive locations for FDI in manufacturing, which involves upgrading existing facilities and focusing on export-oriented manufacturing, in particular in the automotive and machinery industries (Hunya 2005). The major benefit of CEE for international business - its European culture - means that clients and manufacturers have a similar mentality, much more than Asian or South American clients. The close proximity to affluent Western European economies is a key advantage. Moreover, EU membership has provided CEE countries with additional credibility among the multinational companies, as a sort of 'quality mark'. As opposed to volatile emerging BRICS economies, new EU member states score favourably in terms of risk, highlighting them as relatively safe environments for investments. In summary, factors like the enlargement of the European Union, globalisation, the role of multinational companies, public sector reform and rapid advances in ICT, have interacted with global political and societal changes and have had a profound impact on subsidiaries located in CEE countries.

Although new EU member states are often portrayed as a coherent group vis-àvis 'old Europe', there are also significant differences within this group. New EU member states can be divided into several sub-groups. They are the Baltic States, former parts of the Soviet Union (Estonia, Latvia, Lithuania), a part of former Yugoslavia (Slovenia), South-Eastern Europe (Bulgaria and Romania, which were the last to join the EU). The core of new EU member states is made up by the so-called Visegrád Group, an alliance of four CEE states - the Czech Republic, Hungary, Poland and Slovakia - for the purposes of cooperation and furthering their European integration. This analytical classification reflects historical and cultural realities of the region. Similarly, a geographical pattern of FDI inflows into CEE countries is highly uneven (Table 1).

The majority of all FDI stock - 65\% (2010) - accumulated in the CEE region has been attracted by the Visegrád countries. The high levels of FDI stocks in these countries are primarily the result of the expansion of the investmentintensive automotive industry from the EU member states to these economies. The production facilities were established mainly to service the host markets (with their high demand for cars), and subsequently the finished products became exported to the EU. FDI contributed to job creation and accelerated the transformation from a command economy to a market economy. 
Table 1 FDI inward stock in ten CEE countries, new EU member states, 1990, 2000, 2010 (millions of US dollars)

\begin{tabular}{|c|c|c|c|c|}
\hline & 1990 & 2000 & 2010 & $\begin{array}{c}\text { Share in CEE10, } \\
2010, \%\end{array}$ \\
\hline \multicolumn{5}{|l|}{ Baltic States } \\
\hline Estonia & - & 2645 & 16438 & 2.6 \\
\hline Latvia & - & 2084 & 10838 & 1.7 \\
\hline Lithuania & - & 2334 & 13449 & 2.1 \\
\hline \multicolumn{5}{|l|}{ South-East } \\
\hline Bulgaria & 112 & 2704 & 47971 & 7.5 \\
\hline Romania & - & 6953 & 70012 & 11.0 \\
\hline \multicolumn{5}{|c|}{ Visegrád Group } \\
\hline Czech Republic & 1363 & 21644 & 129893 & 20.3 \\
\hline Hungary & 570 & 22870 & 91933 & 14.4 \\
\hline Poland & 109 & 34227 & 193141 & 30.2 \\
\hline Slovakia & 282 & 4746 & 50258 & 7.9 \\
\hline \multicolumn{5}{|c|}{ Former Yugoslavia } \\
\hline Slovenia & 1643 & 2893 & 15022 & 2.4 \\
\hline Total & 4079 & 103101 & 638955 & 100 \\
\hline
\end{tabular}

Source: compiled by the author based on UNCTAD (2011:191)

Although the CEE countries have followed slightly different privatisation and FDI promotion strategies, the commitment to use FDI for industrial restructuring (especially in medium high-tech industries) was very pronounced in virtually all CEE economies. Overall, the growth of FDI stocks has been impressive. Poland, for example, increased its FDI stock by a factor of 1772 over a 20-year period, from 109 million US dollars in 1990 to 193 billion US dollars in 2010. Poland, now the first largest FDI recipient among the ten CEE states, with 193 billion US dollars, or $30.5 \%$ of the total CEE10 FDI stock, was not the first to start the race for FDI among the CEE countries. Hungary, presently holding $14.4 \%$ of the total FDI stock accumulated in ten CEE countries and new EU member states (Table 1), was the first to open its economy to FDI in 1989. The 'first mover strategy' had a positive impact and allowed the country to attract several large multinational companies who were interested in the entire CEE region. Both Poland and Hungary started offering investment incentives to foreign multinational companies from the early 1990s onwards. 
Originally, the Czech Republic and Slovakia did not grant any investment incentives and multinational companies were not welcome to the privatisation process; both countries relaxed their investment regimes in the late 1990s. The Czech Republic introduced its investment incentives scheme in May 1998 and Slovakia followed suit in 2000. In the Czech Republic, from its formulation, the investment incentives scheme was coherent with the EU regulations on state aid, and it was further adjusted to these rules later on. The investment boom can be explained by several factors, in particular by the low starting levels and largescale privatisation of former (inefficient) state-owned enterprises at the beginning of the 1990s. The 'FDI-friendly' regime of the Czech Republic has propelled it to the second place in the FDI ranking, with the inward FDI stock of 130 billion US dollars, or $20 \%$ of the total (Table 1). Slovakia's poor performance in terms of attracting FDI in the 1990s is due to an economic slowdown in the 1994-98 period as a result of the crony capitalism and other fiscal policies of Prime Minister Vladimír Mečiar's government. FDI inflows, however, recorded strong growth in the 2000s.

Overall, it can be seen that the Czech Republic, Hungary and Poland have emerged as the key FDI destinations within the CEE region. At the same time, attitudes to foreign investments and FDI promotion policies have differed to a certain extent. Several authors (Meyer 1998; Hunya 2000; Holland et al. 2000) have put forward a number of conclusions regarding the economic transition in the CEE region and the role of FDI: (1) subsidiaries deepen trade connections through high levels of export and foreign trade; (2) subsidiaries have a higher productivity, higher profits and higher shares of $R \& D$ investment compared to domestic firms; (3) foreign multinationals have been playing a crucial role in the restructuring of existing sectors (electronics, automotive) and introducing new ones (banking, telecom); (4) despite of this positive influence, the effects of FDI remain localised and the extent of spillovers is often limited.

\section{Literature Review}

The theoretical foundations for this paper are resource-based view of the firm, core competence and dynamic capabilities. These streams of literature provide a background and understanding of the importance of intangible assets for a modern business organisation. A related stream of literature applies this idea to the case of subsidiaries of multinational companies and develops the argument

towards the subsidiary-specific advantages (Rugman/Verbeke 2001). Furthermore, modern multinational companies are viewed as dynamic corporate networks that actively exchange knowledge.

\section{Resource-based view, core competence and dynamic capabilities}

The fundamental principle of the resource-based theories of the firm is that a competitive advantage of the firm lies in its possession and application of a bundle of critical resources at its disposal, which make up its 'core competency'. 
This idea was firstly expressed by authors like Penrose (1959), Wernerfelt (1984), Rumelt (1984), but only received its full acknowledgement in the 1990s - Prahalad and Hamel (1990), Barney (1991), Campbell and Luchs (1997). The seminal paper by Prahalad and Hamel (1990) describes 'distinctive' or 'core' 'competences' as '... the collective learning in the organisation, especially how to coordinate diverse production skills and integrate multiple streams of technology' (Prahalad/Hamel 1990:82). In the resource-based view, vertical integration and diversification are the key strategies for benefiting from scarce, firm-specific capabilities, which are difficult (or impossible) to sell on intermediate markets. These models underscore economies of scope, derived from firm-specific knowledge from one activity, that are used to enter new activities and markets (Peteraf 1993). Overall, the resource-based theory of the firm emphasises maximising rents deriving from the exploitation of unique resources and capabilities in contrast to traditional models, where a competitive market position brings economic (monetary) profits.

Early contributors to the resource-based view equated resources and capabilities. For example, Barney (1991:101) defines resources as including 'all assets, capabilities, organizational processes, firm attributes, information, knowledge, etc; controlled by a firm that enable the firm to conceive of and implement strategies that improve its efficiency and effectiveness'. The distinction became more strongly pronounced in the mid-1990s, starting with the work by Amit and Schoemaker (1993), who argued that resources can be divided into resources and capabilities. Resources can be traded and are non-specific to the firm, while capabilities are firm-specific and are used to utilise the resources within the firm, such as implicit processes designed to transfer knowledge within the firm (Makadok 2001). Following the resource-based view, a competitive advantage stems from firm-specific resources and the way they are organised and combined to enable firms to outperform their competitors. While the core competence of a firm / subsidiary are established in a specific time period, they are mainly the result of an accumulation of tangible and intangible factors over time.

By the end of the 1990s, the focus had shifted towards the dynamic nature of sustained competitive advantage. The dynamic capabilities view of competitive advantage has focused on the capabilities that allow firms to adapt to changes in their environments. The idea of 'dynamic capabilities' was introduced in the seminal paper by Teece et al. (1997). As a theoretical concept, it emerged from the criticism directed at the resource-based view, arguing that the resource-based view did not take factors relating to the development of the resource base and capabilities of the firm into account.

Teece et al. (1997) define dynamic capabilities as 'the firms' ability to integrate, build, and reconfigure internal and external competences to address rapidly changing environments'. Dynamic capabilities are not a single unit; instead, they 
take on in different forms and perform different tasks (Helfat et al. 2007). Obviously, since dynamic capabilities are by definition intangible and abstract, there are obvious difficulties in identifying and measuring them. There are inevitably problematic, ambiguous and obscure causalities (Williamson 1999). In some situations, the origin of a competitive advantage is unclear and interpretations of competitive analysis may be left in the shadows.

\section{Subsidiary-specific advantages and subsidiary competence}

Multinational companies compete on the basis of unique assets that they control and transfer across the national borders: firm-specific advantages (Rugman 1996), ownership advantages (Dunning 1998; Dunning/Lundan 2008) or resources and capabilities (Barney et al. 2001). It is these unique assets that enable foreign-owned subsidiaries to compete in a foreign host environment and overcome the 'liability of foreignness' (Zaheer 1995). The subsidiary should be competitive vis-à-vis other subsidiaries in its corporate network and vis-à-vis local firms in the host economy in order to sustain its competitive position and keep developing. Since subsidiaries belong to both the corporate network and to the host economy, they use resources that are both firm-specific and locationbound. In other words, there are 'subsidiary-specific advantages' (Rugman/Verbeke 2001).

Local context is a key determinant of the subsidiary-specific advantages creation. As shown by Meyer and Peng (2005), in the case of Central and Eastern Europe, the resource endowment and the institutional framework of the host economies affect the characteristics, survival and development of subsidiaries. In fact, by embedding into their host environment and sourcing knowledge and expertise from domestic firms and organisations, subsidiaries develop their competence, which is ultimately expected to be beneficial to the entire multinational network (Birkinshaw et al. 1998; Andersson/Forsgren 2000; Andersson et al. 2002).

Following White and Poynter's (1984) classification of subsidiaries, Schmid (2003) suggests that competence and capabilities can be created in three different dimensions: functions (one or several value-adding activities), products (all value-adding activities for a specific product or service (or a certain area of business) or processes. In this study, we focus on the competence and capabilities in specific functions. A fundamental guiding idea here, as argued by Schmid (2003), is that superior competences or capabilities can relate to any functions, which means that this superior competence can be created even in low value-added functions. Therefore, it should be noted that the concept of capabilities is not the same as R\&D or innovativeness.

In the same vein, Asmussen et al. (2009:45) call for a multidimensional view of subsidiary competence: 'The term subsidiary competence captures both the existence of the activity in the value chain and proficiency in that activity - the 
former being a prerequisite for the latter'. Furthermore, Asmussen et al. (2009) cluster subsidiary competences into functions in three distinctive groups: supply competence (purchasing, logistics and distribution), technical competence (research, development, production of goods/services), and market competence (marketing and sales).

\section{Sources of competence and knowledge flows}

Subsidiaries can tap knowledge and competence from a variety of sources. They build relationships with various market and non-market actors on various levels - locally, regionally, nationally and, in some cases, even globally. In these networks subsidiaries exchange resources, including goods or unfinished products, financial resources, and knowledge and information. As a result, the subsidiary competence is generated in the process of the day-to-day operations and as such depends on both local and corporate embeddedness.

Following Kuemmerle (1997), three types of knowledge flows can be identified: 'sub-HQ', 'sub-sub' and 'sub-local'. Sub-HQ Flows are 'vertical knowledge flows' between the subsidiary and its parent company. It is a two-way flow from the HQ to the subsidiary (traditional flows) and vice versa (a modern view on the active role of the subsidiary creating value for the parent company). Next are the Sub-Sub Flows or 'horizontal knowledge flows' between the subsidiary and its sister subsidiaries (Nobel/Birkinshaw 1998), which are becoming increasingly important with the development of IT (directly connecting subsidiaries) and more pro-active position of many subsidiaries, i.e. subsidiary initiative (Bartlett/Ghoshal 1989; Birkinshaw 1998, 2003; Birkinshaw et al. 2005).

Finally, Sub-Local Flows are knowledge flows between the subsidiary and its local environment, such as local universities, research institutes, customers, suppliers and competitors, which enable the subsidiary to learn and enhance its local competence. The role of the subsidiary in this case is to assess, filter and choose the knowledge flows (Mudambi 2002). This embeddedness is dependent upon the formation of formal and informal social networks. Obviously, these flows may go in an opposite direction, when agents in a local environment receive knowledge from the subsidiary, which is typically the case of spillovers, and is extensively studied in a mainstream literature on FDI.

Overall, in the quest for new knowledge, subsidiaries may turn to any of these sources and initiate any of these three types of knowledge exchange. This is consistent with the idea that innovation takes place by the recombination of existing knowledge (Kogut/Zander 1992; Nonaka 1994). Exposure to various external contacts is essential for learning (McEvily/Zaheer 1999). Access to a knowledge source as such, however, is not enough. A critical factor is the distinction between codified and tacit knowledge (Polanyi 1966). Knowledge flows are particularly problematic when it comes to tacit knowledge, which is 
acquired by and stored within individuals and cannot be easily transferred or traded as a separate entity. Therefore, tacit knowledge requires strong and established ties between the parties concerned before it can be transferred (Lane/Lubatkin 1998; Nobel/Birkinshaw 1998; Cantwell/Piscitello 1999). The absence of such strong ties and of two-way interaction is one of the key barriers to the transfer of knowledge within multinational companies. Motivational factors play a crucial role as well; in other words, the source and the target units of knowledge transfer should have the motivational disposition for such a twoway transfer (Gupta/Govindarajan 1991, 2000). Another factor that can affects knowledge flows is psychic distance (Johanson/Vahlne 1977). Psychical proximity reduces the level of uncertainty that firms face in new markets, and for subsidiaries it is easier to learn and exchange knowledge in psychically closer countries.

\section{Research Questions}

The body of literature reviewed in the previous section was mainly developed within the context of advanced Western economies and companies. Competence-building in subsidiaries located in developing economies or in transition economies has receive far less attention, based mainly on the assumption that any type of superior competence can only be generated in the parent company based in the West and channelled down to the subsidiaries located in the less advanced countries.

\section{Sources of competence}

A key feature of the dynamic capability models is their focus on how new capabilities can be created while exploiting existing capabilities within a competitive external environment. Connections with customers, suppliers, research institutes and other agents provide knowledge diversity to subsidiaries, which can increase the depth and breadth of the accumulated competences. In line with Holm and Pedersen (2000), we identify several broad categories of the sources of competence: (1) corporate headquarters, (2) sister subsidiaries / other units in a corporate network, (3) specific customers / suppliers / competitors on a local market, (4) specific customers / suppliers / competitors abroad, (5) university or research centres in a host economy. Connections with customers, suppliers, research institutes and other agents can be important network resources for the development of subsidiary competences. The network resources increase the subsidiaries' awareness of and accessibility to knowledge.

Corporate network: It is widely acknowledged that the corporate network remains a prime source of knowledge and competence for most subsidiaries who receive the up-to-date technology, as well as other knowledge, from the corporate headquarters. They actively exchange this knowledge and tacit skills with the peer subsidiaries and other units in the corporate network. 
Specific customers, suppliers or competitors on a local market: Although it has been increasingly argued that the forces of globalisation can lead to cultural and institutional convergence, companies entering foreign markets still face the liability of foreignness (Zaheer 1995), i.e. cultural differences at home and in the host markets. In an effort to overcome this liability, subsidiaries need to learn to operate in the local market and enhance their local embeddedness. Those that are strongly embedded in inter-organisational relationships are more likely to develop competitiveness (Schmid/Schurig 2003; Davis/Meyer 2004). These inter-organisational relationships are formed with other firms, R\&D agencies (universities, research institutes), local authorities, chambers of commerce, etc.

Specific customers, suppliers or competitors abroad: Exposure to a specific customer, suppliers or competitor abroad raises awareness among the subsidiary's management regarding international standards, as well as managerial and technological practices. Such exposure is especially relevant to subsidiaries that serve foreign markets by producing their goods for export.

Local universities or research institutes: The internationalisation of corporate $\mathrm{R} \& \mathrm{D}$ has been well documented in empirical studies and analysed in academic literature (Kuemmerle 1997; Granstrand 1999). Traditionally, R\&D was always carried out at the headquarters, but recently many modern multinational companies have started decentralising their $R \& D$ activities to various subsidiaries. For most decentralised R\&D activities, local sources of knowledge and technology are crucially important, with multinational companies tapping into local resources and acquiring technology.

This study is based on the main premise that the ability on the part of subsidiaries to exploit or augment their competences is a function not only of their own resources, but also of their capability to utilise complementary resources. Thus, it is essential to investigate complementarities in the access to different sources of competences and various patterns of this process, which leads to the following Research Question:

$\boldsymbol{R Q}$ 1: What are the patterns of access to the sources of competences and complementarities between these sources?

\section{Competences in specific business activities}

The idea of complementarity can be applied to the sources of competence as well as to the competences in particular business functions performed by the subsidiary. This notion of synergy is a prime message of the competence view of the firm, stemming from the classical contribution by Penrose (1959). The firm as a whole is much more than the sum of its parts (Nelson/Winter 1982). Likewise, the resource-based theories emphasise economies of scope derived from firm-specific knowledge from one activity that are then used to start up 
new activities (Peteraf 1993). Hence, it is reasonable to expect that the skills and competences in specific functions are complementary to each other and that synergy can be achieved.

Subsidiary may contain various business functions. Williams (1998) and Holm and Pedersen (2000) identified seven generic functions of a manufacturing subsidiary, while Schmid (2003) identified eight and Hogenbirk and Van Kranenburg (2006) - six. Based on these studies and interviews with experts, nine corporate functions are defined in this paper: (1) basic and fundamental research, (2) product development, (3) manufacturing of goods, (4) assembly, (5) marketing, (6) sales and after sales, (7) distribution, (8) logistics and (9) purchasing and procurement. The distinction between manufacturing and assembly is intentional. The assembly of imported parts is typical done in countries with a relatively cheap labour force and it has a very limited effect on technological capacity improvement. On the other hand, manufacturing implies more advanced production processes and entails technological capacity improvement.

Competence building in one function may require knowledge and expertise in another. A prime example is the complementarities in business activities like product development and research, often referred to together as R\&D. On the other end, some functions may not be mutually relevant. We aim to explore idiosyncratic patterns of complementarities between particular functional competences and the way these competences evolve. The following Research Question is formulated:

$\boldsymbol{R} Q$ 2: What are the patterns of functional competences' evolution and the complementarities between functional competences?

\section{Data and Methodology}

The data were collected in a self-administered web-based survey conducted in 2008 among foreign-owned companies in the Czech Republic, Hungary and Poland. In order to conduct an effective survey and achieve a higher response rate, it is essential to have a full name and position of a subsidiary senior manager, because an invitation to participate in the survey should be personalised. Next, a valid e-mail address of this person should be available. Several directories were considered, such as Dun \& Bradstreet database and national registers of firms. They did not satisfy the required criteria, because they either did not discriminate between domestic firms and foreign subsidiaries, or they contained no contact information regarding the subsidiary management. In the end, the Business Monitor International's 2008 Directory of Foreign Firms was used to form a sample of respondents. This is a comprehensive list covering a majority of foreign firms in the countries we examined and it also contains the names and personal e-mail addresses of senior executives of foreign 
subsidiaries. As claimed by the publishers, the directory is 'The No. 1 source for corporate data on foreign subsidiaries, joint ventures and associate companies'.

Only manufacturing subsidiaries (or those supporting manufacturing) were selected, while service firms were excluded from the sample. We used a detailed questionnaire that represented an extended and elaborated version of other questionnaires used in the academic research on subsidiaries (e.g. Williams 1998; Holm/Pedersen 2000; Tavares/Young 2006). The wording was revised after the comments by experts in the field and practitioners. A detailed questionnaire of 31 questions designed to capture all aspects of the strategy and evolution of the subsidiary was finally produced. A pilot survey was conducted in April - May 2008 and suggestions from the subsidiary managers were included in the final version of the questionnaire.

In late May - early June 2008, 1628 e-mail notifications were sent out, 342 of which bounced because the e-mail address was incorrect. In all, we received 54 responses. Follow-up enquiries to non-respondents were conducted twice, in June and July. The timing was chosen intentionally as the summer is the offpeak business period and general managers have more free time which can be devoted to answering the questionnaire. Even though some managers were on holiday, and respective notifications were received, they answered the questionnaire after they returned to the office. As a result of these efforts, an additional 46 responses were received, bringing the total to 100 usable responses, representing a response rate of 7.78 per cent, which is well within the normal expectations of a survey of this kind, considering the typically low response rates in international management studies in general (Harzing 1997, 2000) and with foreign-owned subsidiaries, emerging economies and web-based surveys in particular (Couper et al. 1999). Jobber and Saunders (1988) note that a 10 per cent response rate in a cross-cultural survey research can serve as a benchmark for response rate expectations. For example, in a study into the performance of foreign subsidiaries in CEE economies, Dikova (2009) reports a response rate of 7.5 per cent.

The quality of the data is very high, with a general level of missing values under 15 per cent. There are reasonable grounds to believe that the sample we obtained is representative. Non-response bias was assessed on a number of variables by comparing early and late respondents, following the widely used method suggested by Armstrong and Overton (1977). Overall, the results indicated that non-response bias was not a problem.

\section{$\underline{\text { Respondents }}$}

In the data gathering process, subsidiary managers (president or chief executive officers of the subsidiaries) were approached, rather than the management of the parent companies, based on the assumption that subsidiary managers are better informed about the performance and day-to-day operation of the subsidiary, and 
about the characteristics of the local market. Subsidiary management is supposed to have a reliable awareness of the subsidiary's competence in various activities. Notifications were sent directly to the e-mails of the subsidiaries' managing directors. At the end of the questionnaire, respondents were asked to identify themselves. While $43 \%$ of the respondents preferred to skip this question on the grounds of confidentiality, the majority of those who did respond were subsidiary managing directors/ presidents.

Reliance on the perception of individual respondents has been a common technique in IB literature. Many seminal papers in the area of subsidiaries studies/ management rely on the perception of managers (e.g. Ghoshal/Bartlett 1988; Birkinshaw et al. 1998). In fact, the bias in the perception of subsidiary managers has its advantages, since it is this very bias that affects the formulation of the subsidiary strategy and evolution.

\section{Intertemporal periods}

We chose two time periods to emphasise the dynamic nature of subsidiary evolution. There is no universally accepted time period for this type of research. For example, Hood and Taggart (1999) conducted a survey in 1995 in which respondents were asked for their views on development in the period from five years before until five years after the survey date. In a survey conducted in 1999, Pearce and Tavares (2000) asked respondents about their current activities, and those pre-1986 and in the future (in 10 years). We follow the suggestion made by Taggart (1998) and Hood and Taggart (1999) to use a period of five years, which seems reasonable. The survey was conducted in 2008, and the respondents are asked about the situation in 2003.

Inter-temporal analysis may have two potential shortcomings; the first of which is selective memory on the part of respondents, while the second one is a probability that a respondent did not work in the current position in the past and hence cannot provide fully credible information. The vast majority of respondents in our sample did work in the same company five years ago. In fact, this type of retrospective analysis is the only realistic way of conducting research.

$\underline{\text { Variables }}$

Functional competence: Subsidiary managers were asked to provide a reflective self-assessment on the level of subsidiary competence in each of the nine specific functions outlined above. A similar approach has been used in several IB studies (e.g. Birkinshaw 1999; Holm/Pedersen 2000; Andersson et al. 2002). The level of competence ranges on a 7-point scale for each business activity, ranging from $1=$ weak to $7=$ strong.

Sources of competences: Subsidiary managers were asked to identify the importance and relevance of each of the five categories for the generation of their business competence. The categories were identified in accordance with 
the categories outlined in Section 4. The idea of 'source' was used in a very flexible manner, encompassing a variety of forms, from informal interaction and learning ('demonstration effect') to formal contractual relationships. For the purposes of this study, the mechanism and nature of these interactions were not of crucial importance. What mattered was the relevance of particular sources of the accumulation of competences. The level of reliance on a sources of competence is measured on a 7-point scale for each business activity, ranging from $1=$ no importance/ no reliance to $7=$ high importance/ strong reliance.

Subsidiaries characteristics: Most subsidiaries in the sample belong to the sectors of electronics and electrical appliances, automobiles and auto components, and mechanical engineering and instruments. Few subsidiaries operate sectors like ICT and software, textile, clothing and footwear, and food processing. The subsidiary size is operationalized through its number of employees: $19 \%$ of the sample are small-sized subsidiaries (1-99 employees), while $46 \%$ are medium-sized subsidiaries (100-999 employees) and $8 \%$ are large subsidiaries (more than 1000 employees). Although 27\% of respondents did not answer this question, this variable was obtained from the secondary data. Regarding the age of the subsidiaries, the distribution is as follows: $37 \%$ of the sample were established (either greenfield or acquisition) in the first half of the 1990s (up to 1995), 30\% in the second half of the 1990s (1995-1999) and 5\% in the 2000s. Some respondents did not answer this question, but this variable was obtained from the secondary data.

Parent companies of subsidiaries in the sample are mainly based in Europe, with the exception of the US (19\% of the sample): subsidiaries of German companies - 19\%, French companies - 8\%, Dutch companies - 7\%, Italian companies $5 \%$, while subsidiaries of companies based in other European countries make up less than $5 \%$. Some $4 \%$ of respondents indicated two countries as the location of the corporate HQ (e.g. US/Japan, Japan/Germany, US/France). This geographical distribution of home countries for the subsidiaries in the sample broadly represents the actual distribution of source countries of FDI inflows and FDI stocks. As for the mode of entry, the majority of subsidiaries in the sample were established as a result of greenfield investment (48\%), while more than a quarter $(26 \%)$ of subsidiaries were founded through the acquisition of a domestic company. Some $26 \%$ of respondents did not provide this information.

This paper uses descriptive statistics and Pearson's correlations between various variables as its main technique. The statistic approach yields important results and makes it possible to answer the research questions formulated in the previous section. We use three levels of significance. Keeping in mind that the study deals with perceived variables, as it is often done in the social sciences and managerial studies in particular, the limits of significance are set to $10 \%$. 


\section{Analysis}

\section{Descriptive statistics of the sources of competence}

Five major sources of competence were identified for this study. Managers were asked to rate the importance of particular sources on a 7-item scale.

The descriptive statistics are presented in Table 2.

Table 2 Descriptive statistics of the sources of competence

\begin{tabular}{l|cccc}
\hline \hline Sources of competences & Mean & $\begin{array}{c}\text { Std. } \\
\text { Error }\end{array}$ & $\begin{array}{c}\text { Std. } \\
\text { Dev. }\end{array}$ & Variance \\
\hline \hline The company headquarters & 5.19 & .150 & 1.429 & 2.042 \\
Another subsidiary/unit in a corporate network & 4.57 & .163 & 1.550 & 2.403 \\
$\begin{array}{l}\text { A supplier, customer or competitor on a local } \\
\text { market }\end{array}$ & 4.56 & .179 & 1.692 & 2.863 \\
A supplier, customer or competitor abroad & 3.23 & .211 & 2.000 & 4.001 \\
A university or research centre in the host country & 2.62 & .188 & 1.794 & 3.217 \\
\hline \hline
\end{tabular}

There are considerable differences in the mean values of the five categories. The highest one, at 5.19, is the headquarters of the multinational companies, meaning that subsidiaries tend to seek advice and support from the parent company. This observation argues in favour of the traditional model of a multinational company where the headquarters is the repository and creator of knowledge, technology and competence. However, another observation supports a more modern view, where sister subsidiaries are also important players in a globally networked multinational company. The mean value is 4.57 for this category.

There is a growing consensus in studies on subsidiaries that relationships with customers, suppliers and other counterparts are crucial to the accumulation of competences in subsidiaries. In our sample, the categories 'a supplier, customer or competitor on a local market' and 'a supplier, customer or competitor abroad' had mean values of 4.56 and 3.23 respectively, which indicates that subsidiaries tend to learn and develop competences from daily operations in their local environment, rather than through interactions on foreign markets. This preliminary finding is in line with modern theories on subsidiary management regarding the embeddedness of subsidiaries in local environments being a crucial measure of success. Subsidiaries manufacturing products for export can fall back on the competences of their parent company, or they can produce semifinished goods for their sister subsidiaries, in which case the reliance on foreign partners as a sources of competence can be minimal. 
Local universities or research centres, finally, have a mean value of 2.62, a low score that is not surprising. By their nature, local universities or research centres can serve as a source of competences only for higher value-added activities, primarily $\mathrm{R} \& \mathrm{D}$, in which many subsidiaries are not involved.

\section{Complementarities in sources of competence}

The standard econometric technique to measure complementarities is the correlation (Cohen et al. 2003). Two random variables are positively correlated if high values of one are likely to be associated with high values of the other. Conversely, they are negatively correlated if high values of one are likely to be associated with low values of the other.

Specifically in the case of the sources of competences, the presence of a positive significant correlation between two sources of competences implies that subsidiaries tend to learn from these sources in a complimentary way. Reliance on one source is complemented by another source. We use Pearson's correlation to establish this complementarity (Table 3). Many sources of competences are complementary, with strong and statistically significant correlations being established between several sources of competence on a pair-wise basis. For the purposes of this study, we pay attention to the sign and the significance level of a correlation coefficient, and not at the magnitude of its value as such.

Table 3 Pearson's correlation of the sources of competence

\begin{tabular}{|c|c|c|c|c|}
\hline The sources of competence & (1) & (2) & (3) & (4) \\
\hline (1) The company headquarters & 1 & & & \\
\hline $\begin{array}{l}\text { (2) Another subsidiary/unit in a corporate } \\
\text { network }\end{array}$ & $.267 * *$ & 1 & & \\
\hline $\begin{array}{l}\text { (3) A supplier, customer or competitor on a } \\
\text { local market }\end{array}$ & -.072 & $.179 *$ & 1 & \\
\hline $\begin{array}{l}\text { (4) A supplier, customer or competitor } \\
\text { abroad }\end{array}$ & $-.203^{*}$ & $.320 * *$ & $.256^{* *}$ & 1 \\
\hline $\begin{array}{l}\text { (5) A university or research centre in the } \\
\text { host country }\end{array}$ & -.032 & .115 & $.247 * *$ & $.245^{* *}$ \\
\hline
\end{tabular}

** significant at the 0.01 level (1-tailed) ;* significant at the 0.05 level (1-tailed).

There is as a positive and significant correlation between the usefulness of the following sources of competence:

$H Q$ and sister subsidiaries: A strong significant and positive correlation between these variables indicates high levels of complementarity in the use of competences between the parent company and the sister subsidiaries, which provides additional empirical support for modern multinational companies as 
diversified networks. The HQ is not the only source of competence, and both vertical and horizontal knowledge flows exist in the multinational company.

Abroad and sister subsidiaries. Likewise, subsidiaries relying on the knowledge base of their sister subsidiaries prefer to complement that knowledge with the expertise of customers/ suppliers/ competitors abroad. This may explain the creation of competence in subsidiaries that target foreign markets (producing for export). Sister subsidiaries producing for export may face similar requirements and demands and their competences may complement the competences obtained from interaction with a particular customer, supplier or competitor abroad.

Local market and sister subsidiaries. Similarly, competence generated through the interaction with sister subsidiaries may be complementary to the competence obtained from a specific customer, supplier or competitor on the local market.

A research institute or university in the host country and a specific customer, supplier or competitor abroad. This strategy may be pursued by subsidiaries tapping into the local knowledge base and using that knowledge to develop new export products.

A research institute or university in the host country and a specific customer, supplier or competitor on the local market. This combination is straightforward, meaning that the subsidiary may be engaged in product developments intended specifically for the local market.

Overall, the results strongly suggest that there are indeed complementarities in the sources of competence, meaning relying on one individual source may be insufficient, and the best results may be achieved from their combination. These findings provide an answer to the Research Question 1, showing various patterns of sourcing of knowledge and competence.

\section{Descriptive statistics of competences in specific business functions}

Subsidiary managers were asked to assess the functional competences of their subsidiary (on a 7-point Likert scale), both for the present (2008) and for the past (2003). The descriptive statistics are presented in Table 4.

First of all, it can be observed that subsidiaries obtain new functions. In all cases, the number of subsidiaries possessing a particular function in 2008 is always higher than it was in 2003 (with the exception of logistics). Concerning the competences in functions as such, the responses ranged from 1 (minimum) to 7 (maximum), i.e. managers made full use of the 7-point scale. The mean values for 2008 pivot around 5.0, whereas the means for 2003 are around 4.35. Overall, the spread in the functions' competences is not high, meaning that none of the functions is perceived as either highly superior or highly inferior by all managers. It is worth noting that the managers were requested to compare their competences to those of the competitors, not the competence in one function in relation to another one. 
Table 4 Descriptive statistics of functional competences

\begin{tabular}{|c|c|c|c|c|c|c|c|}
\hline Function & Year & $\mathrm{N}$ & Min & Max & Mean & $\begin{array}{l}\text { Std. } \\
\text { Dev. }\end{array}$ & Variance \\
\hline \multirow{2}{*}{ Research } & 2008 & 13 & 3 & 7 & 5.23 & 1.235 & 1.526 \\
\hline & 2003 & 6 & 2 & 7 & 4.33 & 1.633 & 2.667 \\
\hline \multirow{2}{*}{ Development } & 2008 & 36 & 3 & 7 & 5.11 & 1.141 & 1.302 \\
\hline & 2003 & 19 & 2 & 7 & 4.68 & 1.293 & 1.673 \\
\hline \multirow{2}{*}{ Manufacturing } & 2008 & 47 & 4 & 7 & 5.55 & 0.880 & 0.774 \\
\hline & 2003 & 42 & 2 & 7 & 4.71 & 1.215 & 1.477 \\
\hline \multirow{2}{*}{ Assembly } & 2008 & 26 & 3 & 7 & 5.35 & 1.056 & 1.115 \\
\hline & 2003 & 27 & 1 & 7 & 4.11 & 1.476 & 2.179 \\
\hline \multirow{2}{*}{ Marketing } & 2008 & 65 & 2 & 7 & 4.92 & 1.080 & 1.166 \\
\hline & 2003 & 58 & 1 & 7 & 4.03 & 1.350 & 1.823 \\
\hline \multirow{2}{*}{ Sales } & 2008 & 76 & 3 & 7 & 5.26 & 1.012 & 1.023 \\
\hline & 2003 & 74 & 2 & 7 & 4.27 & 1.231 & 1.515 \\
\hline \multirow{2}{*}{ Distribution } & 2008 & 57 & 3 & 7 & 4.84 & 1.099 & 1.207 \\
\hline & 2003 & 55 & 1 & 6 & 4.25 & 1.308 & 1.712 \\
\hline \multirow{2}{*}{ Logistics } & 2008 & 43 & 2 & 7 & 4.91 & 1.171 & 1.372 \\
\hline & 2003 & 44 & 1 & 6 & 4.39 & 1.185 & 1.405 \\
\hline \multirow{2}{*}{ Purchasing } & 2008 & 45 & 3 & 7 & 5.09 & 1.062 & 1.128 \\
\hline & 2003 & 40 & 1 & 6 & 4.45 & 1.239 & 1.536 \\
\hline
\end{tabular}

\section{Evolution of competences}

Since a subsidiary's competences are unequally distributed among its functions, it is to be expected that the evolution of these competences will also be highly heterogeneous. This paper assesses competences on a 7-point scale, estimating to what extent the competences evolved from 2003 to 2008, based on the survey data. In several subsidiaries, new functions emerged, with a particular level of competences, while in others, functions were lost. For the purposes of analysis, only functions that existed both in 2003 and 2008 are included. Figure 1 presents the results. 
Figure 1 Growth of functional competences over the period of 2003-2008

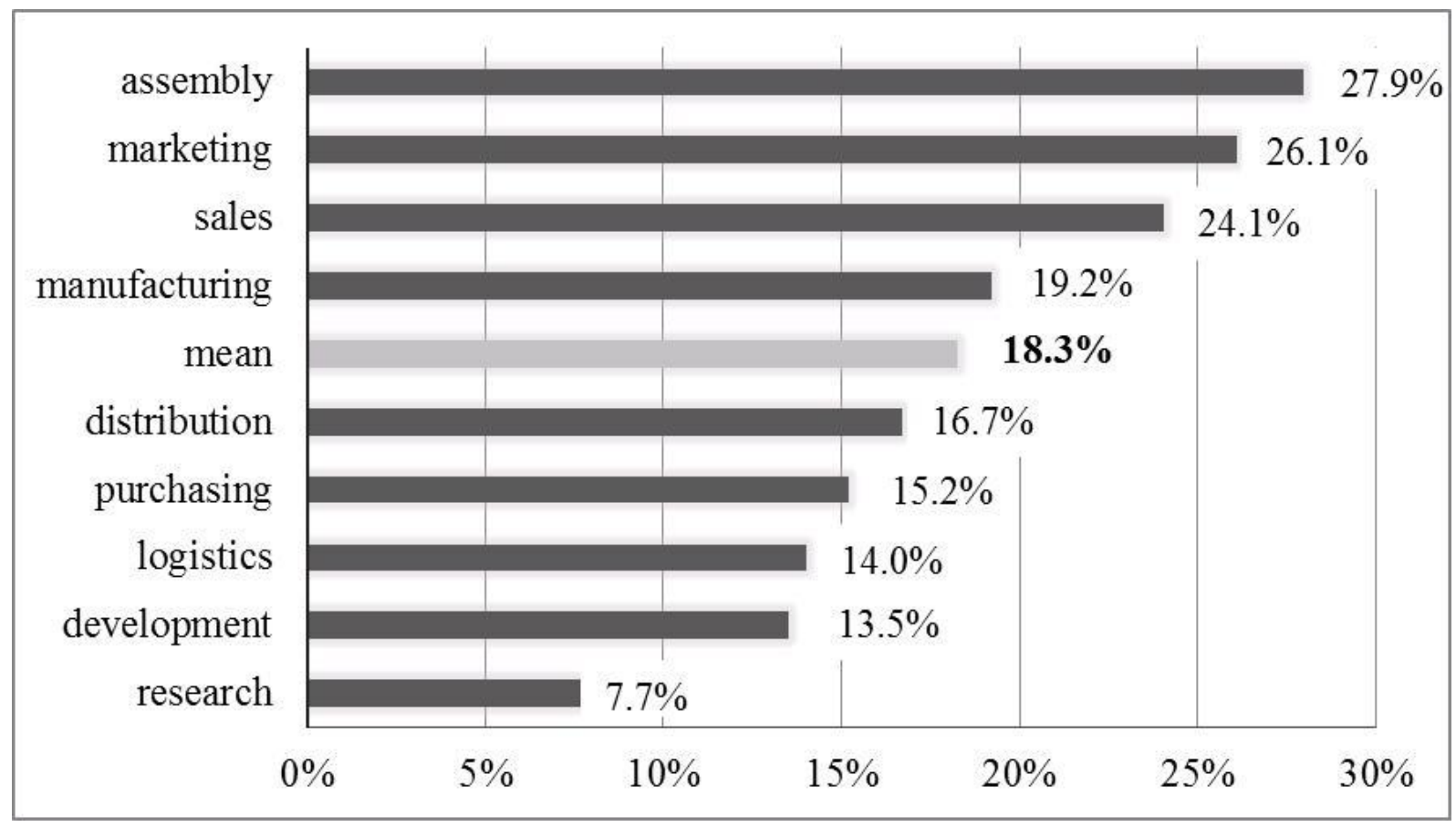

Overall, the mean coefficient constituted an $18.3 \%$ growth. The fact that subsidiary managers perceive the growth of their subsidiaries' competences is in itself remarkable. However, as interesting as it may be, this finding does not provide any insight in the actual growth of competences. The average number in itself is not crucial to the analysis. What is more important is the distribution of particular corporate functions around the mean.

The growth of competences in four functions was higher than the mean, while it was below the mean in five other functions. The growth of competence in assembly, marketing, sales and manufacturing was above the mean. These results confirm what was expected. First of all, manufacturing and assembly are two core functions of subsidiaries in the sample, because manufacturing subsidiaries were explicitly selected, and therefore high levels of growth in these core functions could be expected. Secondly, high levels of growth with regard to competences in marketing and sales are also not surprising. For many subsidiaries, sales (and related marketing) are an important part of their business model, particularly for those servicing local markets. Since these functions do not require advanced and new expertise, the learning process is fast and the growth of competences is above the mean. Moreover, all these four functions are widely present in a variety of companies, both subsidiaries and local firms, which means there is a high potential for mutual learning.

As for the functions below the mean, they seem to be supportive of the core functions, and many of them have traditionally been executed by the parent companies. A number of subsidiaries do not possess these functions at all. 
Distribution, purchasing and logistics are immediately below the mean, as the these competences accumulate slowly. As was to be expected, research and development are at the bottom of the ranking. The growth of the competence is minimal in research (less than half the mean), while development is second from the bottom, which shows the complexity of these two functions and indicates that developing competences in these areas is a difficult process involving a great degree of learning.

\section{Complementarities in business functions}

Next, complementarities in the competences in particular functions are also estimated using the correlation technique. Pearson's correlation yielded the following results (Table 5).

Table 5 Pearson's correlations of functional competences

\begin{tabular}{|c|c|c|c|c|c|c|c|c|}
\hline $\begin{array}{l}\text { Functional } \\
\text { competences }\end{array}$ & (1) & (2) & (3) & (4) & $(5)$ & (6) & (7) & (8) \\
\hline (1) Research & 1 & & & & & & & \\
\hline (2) Development & $.730 *$ & 1 & & & & & & \\
\hline (3) Manufacturing & .636 & $\begin{array}{l}.577 \\
* *\end{array}$ & 1 & & & & & \\
\hline (4) Assembly & .945 & .293 & $.761 * *$ & 1 & & & & \\
\hline (5) Marketing & .484 & .244 & .256 & .123 & 1 & & & \\
\hline (6) Sales & .364 & -.009 & .044 & .275 & $.417 * *$ & 1 & & \\
\hline (7) Distribution & .513 & .271 & $.541^{* *}$ & $.546^{*}$ & $.432 * *$ & $.559 * *$ & 1 & \\
\hline (8) Logistics & .554 & .357 & $.565^{* *}$ & $.608 *$ & $.507 * *$ & $.419 * *$ & $.736^{* *}$ & 1 \\
\hline (9) Purchasing & .000 & .239 & .325 & $.747 * *$ & .070 & $.404^{*}$ & $.458 *$ & $.634 * *$ \\
\hline
\end{tabular}

* significant at the 0.05 level (2-tailed); ** significant at the 0.01 level (2-tailed)

Competences in basic and fundamental research are highly and significantly correlated with those in product development, which is to be expected, given the almost indivisible nature of research and development. Competences in product development, on the other hand, are positively and significantly correlated to competences in the manufacturing of goods, which indicates that the function of the product development, as a rule, has its roots in the manufacturing. High levels of competence and specialisation in manufacturing may then evolve into product development.

In a similar vein, competences in the manufacturing of goods and assembly are highly and significantly correlated. Manufacturing is portrayed as a more 
advanced form of assembly, and hence skills and competences used in assembly form a necessary basis for the competences in the manufacturing of goods. Marketing and sales and after sales are also related, which is evident, considering the fact that these activities are related by their nature.

The level of competence in distribution is positively related to manufacturing, assembly, marketing and sales. Competences in logistics are also interlinked with the competences in these functions, as well as with those in distribution. Finally, competences in purchasing and procurement are related to those in assembly, sales, distribution and logistics.

Functional competences at the bottom have more complementarities than those at the top, effectively meaning that the more common the business activities are, the more complementarities there are with other activities, and the more possibilities there are for cross-functional learning.

In an effort to answer Research Question 2, our intention was to identify various patterns with regard to these complementarities, and we were indeed able to establish strong, positive and significant correlations. As was to be expected, the complementarity is not random, but it is determined by the complexity and added value of each particular activity.

\section{Discussion and Conclusions}

The main objective of the paper was to examine the competences of subsidiaries located in the new EU member states. With the internationalisation of corporate $\mathrm{R} \& \mathrm{D}$, the assumption has been that superior competence and capabilities can be generated only in R\&D. The results of this study clearly show that competences can be formed in a variety of corporate functions. Even subsidiaries that have no R\&D capabilities at all can share their knowledge, techniques and competences in other functions, even in cases where those functions have little added value, for instance (Schmid 2003).

We found empirical support to validate the claim that subsidiary competences evolve over time. However, the most valuable results of this study concern the distribution of this growth across the functions, which was faster in the most widespread and less value-adding functions, while it was slower in more advanced and rare functions. Subsidiary competences should be seen as a multidimensional phenomenon (Asmussen et al. 2009). We found significant and positive complementarities in the levels of competences in particular corporate functions.

Further, the sources of the competences are also complementary. While the competences as such are developed within individual subsidiaries, the input in this process can vary. The best results may be achieved when the competence is tapped not from one but from different sources. Several combinations of sources were discussed and analysed. The empirical investigation shows that 
subsidiaries rely on the corporate headquarters for their competences, often complemented by sister subsidiaries. Customers, suppliers and competitors on local markets or abroad also serve as important sources of competences, albeit to a lesser degree. Finally, local universities or research centres emerge as sources of competence as well, yet with the lowest ranking, since it may be important only to subsidiaries with creative functions and capabilities, which are numerous in the new EU member states.

\section{Policy implications}

This study calls for a rethink of the role of subsidiaries in a host economy and their source base. Host country governments should abandon the 'pipeline' and 'spillover' approaches whereby it is assumed that foreign subsidiaries receive competences and technology only from the corporate headquarters, and the role of a host country government, in turn, is to maximise spillovers from the subsidiaries to domestic firms. Foreign subsidiaries should be regarded as equitable partners whose knowledge base is not given and static. Subsidiaries can tap into a variety of sources to acquire competences, depending on the particular corporate function. Enhancing the collaboration between subsidiaries and local universities and research institutes is definitely important to both sides, for the generation of competences in advanced functions.

\section{Managerial implications}

The findings from this exploratory research offer insight into the process whereby subsidiary competences are created within a corporate network, suggesting that subsidiaries rely on a variety of sources to generate their competence base. We suggest that individual subsidiaries should specialise in particular functional areas, competences or knowledge and make other parts in the corporate network - the HQ and sister subsidiaries - aware of their special competences. In doing so, they enhance the corporate embeddedness and reliance on them by other units within the corporate network. Moreover, it is advisable to specialise in the type of knowledge or resource that the corporate group intends to source in the host country. The technological profile of a subsidiary should match the technological profile of the host country. The subsidiary may adopt an integrative approach by expanding relationships within the network of the multinational company and by becoming deeply involved in the learning process at a corporate level and in the corporate decision-making process, which may provide opportunities for its evolution and rise in the corporate network.

In principle, both the subsidiary and parent company management share a common vision of the growth and qualitative development of the corporation and all its parts/subsidiaries. However, the HQ and subsidiary management may have divergent short-term operational interests. As for the parent companies themselves, corporate internationalisation strategies are multifaceted and 
multinational companies have to formulate strategies on a number of dimensions. Many multinational companies continue to adhere to the old organisational practice whereby competence, technology and innovation are generated at home (the HQ) and then transferred to their overseas subsidiaries. In this study, we argue that this model should be reconsidered. Corporate headquarters should be aware of the resources, competences and capabilities at the subsidiary level. Multinational companies should strive to make the most of their networks of foreign subsidiaries. This will require changes in strategy, structure and culture. HQ may use subsidiaries as scanners and acquirers of information from a variety of sources in various national innovation systems.

Although many multinational companies have acknowledged this shift, not all of them have recognised that this development requires a change in the management and thinking. Not all parent companies make use of their subsidiaries' potential; and subsidiaries have much more to offer than it is generally believed. A practical suggestion for corporate headquarters is to establish a portfolio of centres of competence within the corporate structures, which would enable them to use specialisation advantages and to leverage different organisation-specific and country-specific resources. Corporate headquarters should design a system of subsidiary performance assessment in which the generation of expertise and knowledge are important performance evaluation criteria, comparable to traditional indicators of operating profit.

The topic of competence-building and transfer is subject to two kinds of culture. Following Hofstede (1997), culture can be seen as organisational culture and national culture that differ from each other when it comes to values and practice.

The cultural dimensions show the overall characteristics of a country. They may significantly influence the transfer of knowledge within enterprises as well as among business partners (Hofstede 1983). The greater the cultural differences between the home country of a multinational company and the country hosting its subsidiary are, the more likely it is that there will be barriers to communication and misunderstandings. Both HQ and subsidiary management should be aware of these (potential) cultural differences. Existing literature has thoroughly treated this topic, and its analysis is beyond the scope of this paper. As a suggestion, practitioners can assess cross-country differences using Geert Hofstede's authoritative framework of 'Cultural dimensions' - Power distance, Individualism, Masculinity, Uncertainty avoidance and Long-term orientation. Although, generally speaking, Eastern European countries are culturally close to Western Europe, there are certain differences that managers need to take into account.

Next, there is the organisational culture. The question of efficient and effective knowledge transfer between a subsidiary and its sister subsidiaries and the HQ should be framed within a broader knowledge management system in the multinational company. Factors and barriers that impede intra-organisational 
knowledge flows will be responsible for deficiencies in knowledge and competence transfer between the subsidiary and other units in the corporate network. Therefore, enhanced knowledge management systems serve as a necessary precondition. There are a number of barriers that may potentially impede the international transfer of competences and knowledge. Authors (Michailova/Husted 2003; Minbaeva et al. 2003; Moeller/Svahn 2004; Riege 2005) have identified a wide range of knowledge transfer facilitators and barriers that managers need to consider. Some of these barriers are: no knowledge of where knowledge is available, no knowledge about the existence of valuable knowledge (O’Dell/Grayson 1998; Gupta/Govindarajan 2000), and the epistemological differences between tacit and explicit knowledge (Nonaka/Takeuchi 1995; Szulanski 2003). Cabrera and Cabrera (2002) have described how certain beliefs, such as not having valuable information that was relevant to others, impeded knowledge-sharing practices. Similarly, Szulanski (1996) found that knowledge sharing is inhibited by three major factors: (1) a lack of absorptive capacity on the part of the recipient, (2) casual ambiguity concerning the knowledge itself and (3) the existence of a strenuous relationship between the sender and the receiver.

We agree with Riege (2005), who claims that the successful sharing of goals and strategies must centre around a knowledge-sharing culture and depend on the synergy of three main factors: (1) the motivation and encouragement of individual employees to purposefully capture, transfer and apply existing and newly generated useful knowledge, especially tacit knowledge, (2) flat and open organisational structures that facilitate transparent knowledge flows, processes and resources; and (3) modern technology that purposefully integrates mechanisms and systems thereby providing a suitable knowledge-sharing platform.

\section{Academic contribution}

Given the importance of capabilities to multinational companies, it is surprising to see that neither the resource-based view of the strategic management nor international business literature have attempted to further explore and explain the development of resources, capabilities, or competencies within foreign subsidiaries, with some notable exceptions, such as Schmid and Schurig (2003) and Asmussen et al. (2009). We have shown that subsidiaries based in new EU member states are not passive recipients of technology from corporate headquarters within a framework of a one-way top-down knowledge flow, but that they are also partners in their respective multinational companies - complex networks consisting of the parent company and heterogeneous sister subsidiaries.

Although existing theory acknowledges that capable and advanced subsidiaries are critical to the success of a multinational company, fairly little is known about 
the creation of resources and capabilities in foreign subsidiaries and about the use of this knowledge (Rugman/Verbeke 2001). This study has identified how vital capabilities of multinational companies and other sources of knowledge and competence influence the competence building of subsidiaries in posttransition economies.

\section{Limitations and Future Directions}

Despite the compelling results, this study also has its limitations. We relied on the data collected in a survey carried out for the purposes of this study. Although every effort was made to include all the relevant variables, in accordance with academic literature, the survey data and econometric analysis by their nature have certain limitations. More detailed clinical case studies of particular subsidiaries have to be conducted, to study the phenomenon of the competence accumulation and its use in the corporate network. On the other hand, the results of such case studies can say little about the general situation. Another limitation is the reliance on self-reporting and self-assessment of the subsidiary managers, a widely used approach in subsidiary management research. It has been suggested that complementing these data with the assessment of subsidiaries' competences by the parent company and sister subsidiaries would be more trustworthy than reliance on only one source. However, given a small response rate among managers, surveying different groups of stakeholders and matching their responses would ultimately lead to a very small sample size.

While the local sourcing of competences appears to be very important to subsidiaries, the existing body of literature on the question under what conditions subsidiaries draw on local sources of competence is still relatively limited. In this study, we have made an exploratory attempt to investigate this phenomenon, and it has become clear that this area has many promising research avenues.

\section{References}

Amit, R./Shoemaker, P. (1993): Strategic assets and organizational rent, in: Strategic Management Journal, 14, 1, 33-46.

Andersson, U./Forsgren, M. (2000): In search of excellence: network embeddedness and subsidiary roles in multinational corporations, in: Management International Review, 40, 4, 329-350.

Andersson, U./Forsgren, M./Holm, U. (2002): The strategic impact of external networks: subsidiary performance and competence development in the multinational corporation, in: Strategic Management Journal, 23, 11, 979-996.

Armstrong, J.S./Overton, T.S. (1977): Estimating non-response bias in mail surveys, in: Journal of Marketing Research, 14, 3, 396-402.

Asmussen, Ch./Pedersen, T./Dhanaraj, Ch. (2009): Host-country environment and subsidiary competence: Extending the diamond network model, in: Journal of International Business Studies, 40, 1, 42-57. 
Barney, J. (1991): Firm resources and sustained competitive advantage, in: Journal of Management, 17, 1, 99-120.

Barney, J./Wright, M./Ketchen, D. (2001): The resource-based view of the firm: Ten years after 1991, in: Journal of Management, 27, 6, 625-641.

Bartlett, C./Ghoshal, S. (1989): Managing across borders. Boston: Harvard Business School Press.

Birkinshaw, J. (1998): Corporate entrepreneurship in network organisations: How subsidiary initiative drives internal market efficiency, in: European Management Journal, 16, 3, 355-364.

Birkinshaw, J. (1999): The determinants and consequences of subsidiary initiative in multinational corporations, in: Entrepreneurship: Theory \& Practice, 24, 1, 9-36.

Birkinshaw, J. (2003): Paradox of corporate entrepreneurship, in: Strategy + Business, 30, 4658 .

Birkinshaw, J./Hood, N./Jonsson, S. (1998): Building firm-specific advantages in multinational corporations: The role of subsidiary initiative, in: Strategic Management Journal, 19, 3, 221-224.

Birkinshaw, J./Hood, N./Young, S. (2005): Subsidiary entrepreneurship, internal and external competitive forces, and subsidiary performance, in: International Business Review, 14, $2,227-248$.

Cabrera, A./Cabrera, E.F. (2002): Knowledge sharing dilemmas, in: Organization Studies, 23, 5, 687-710.

Campbell, A./Luchs, K. (1997): Core competency-based strategy. International Thomson Business Press.

Cantwell, J./Piscitello, L.T. (1999): The emergence of corporate international networks for the accumulation of dispersed technological competences, in: Management International Review, 39, 2, 123-147.

Cohen, J./Cohen P./West, S.G./Aiken, L.S. (2003): Applied multiple regression/correlation analysis for the behavioural sciences. Hillsdale, NJ: Lawrence Erlbaum Associates.

Couper, M.P./Blair, J./Triplett, T. (1999): A comparison of mail and e-mail for a survey of employees in federal statistical agencies, in: Journal of Official Statistics, 15, 1, 39-56.

Davis, L./Meyer, K. (2004): Subsidiary research and development, and the local environment, in: International Business Review, 13, 3, 359-382.

Dikova, D. (2009): Performance of foreign subsidiaries: Does psychic distance matter? in: International Business Review, 18, 1, 38-49.

Dunning, J.H. (1998): Location and the multinational enterprise: A neglected factor? in: Journal of International Business Studies, 29, 1, 45-66.

Dunning, J.H./Lundan, S. (2008): Institutions and the OLI paradigm of the multinational enterprise, in: Asia Pacific Journal of Management, 25, 4, 573-593.

Ghoshal, S./Bartlett, C.A. (1988): Creation, adoption and diffusion of innovations by subsidiaries of multinational corporations, in: Journal of International Business Studies, 19, 3, 365-388. 
Granstrand, O. (1999). Internationalization of corporate R\&D: a study of Japanese and Swedish corporations, in: Research Policy, 28, 2-3, 275-302

Gupta, A.K./Govindarajan, V. (1991): Knowledge flows and the structure of control within multinational corporations, in: Academy of Management Review, 16, 4, 768-792.

Gupta, A.K./Govindarajan, V. (2000): Knowledge flows within multinational corporations, in: Strategic Management Journal, 21, 4, 473-496.

Gupta, A.K./Govindarajan, V. (2000): Knowledge management's social dimension: lessons from Nucor Steel, in: Sloan Management Review, 42, 1, 71-80.

Harzing, A. (1997): Response rates in the international mail surveys. Results from a 22country study, in: International Business Review, 6, 6, 641-665.

Harzing, A. (2000): Cross-national mail surveys: Why do response rates differ between the countries? in: Industrial Marketing Management, 29, 3, 243-254.

Helfat, C./Finkelstein, S./Mitchell, W./Peterhaf, M./Teece, D./Winter, S. (2007): Dynamic capabilities: Understanding strategic change in organisations. Malden, MA: Blackwell Publishing.

Hofstede, G. (1983): The cultural relativity organizational practices and theories, in: Journal of International Business Studies, 14, 2, 75-89.

Hofstede, G. (1997): Cultures and organizations: software of the mind, London: McGraw Hill.

Hogenbirk, A./Van Kranenburg, H. (2006): Roles of foreign owned subsidiaries in a small economy, in: International Business Review, 15, 1, 53-67.

Holland, D./Sass, M./Benacek, V./Gronicki, M. (2000): The determinants and impact of FDI in Central and Eastern Europe: a comparison of survey and econometric evidence, in: Transnational Corporations, 9, 3, 163-213.

Holm, U./Pedersen, T. (2000): Introduction and overview, in: Holm, U./Pedersen, T. (eds.): The emergence and impact of MNC centres of excellence: A subsidiary perspective, London: Macmillan.

Hood, N./Taggart, J. (1999): Subsidiary development in German and Japanese manufacturing subsidiaries in the British Isles, in: Regional Studies, 33, 6, 513-528.

Hunya, G. (2000): Integration through Foreign Direct Investment. Cheltenham: Edward Elgar.

Hunya, G. (2005): WIIW Database on Foreign Direct Investment in Central, East and Southeast Europe 2005: Opportunities for Acquisition and Outsourcing. Vienna: Vienna Institute for International Economic Studies.

Jobber, D./Saunders, J. (1988): An experimental investigation into cross-national mail survey response rate, in: Journal of International Business Studies, 19, 3, 483-489.

Johanson, J./Vahlne, J. (1977): The internationalisation process of the firm - a model of knowledge development and increasing foreign market commitments, in: Journal of International Business Studies, 8, 1, 22-32.

Kogut, B./Zander, U. (1992): Knowledge of the firm, combinative capabilities, and the replication of technology, in: Organization Science, 3, 3, 383-397.

Kuemmerle, W. (1997): Building effective R\&D capabilities abroad, in: Harvard Business Review, 75, 2, 61-70. 
Lane, P.J./Lubatkin, M. (1998): Relative absorptive capacity and interorganizational learning, in: Strategic Management Journal, 19, 5, 461-477.

Makadok, R. (2001): Toward a synthesis of the resource-based view and dynamic-capability views of rent creation, in: Strategic Management Journal, 22, 5, 387-401.

McEvily, B./Zaheer, A. (1999): Bridging ties: a source of firm heterogeneity in competitive capabilities, in: Strategic Management Journal, 20, 12, 1133-1156.

Meyer, K. (1998): Direct investment in economies in transition: Making Central European industries competitive. Cheltenham: Edward Elgar.

Meyer, K./Peng, M. (2005): Probing theoretically into Central and Eastern Europe: Transaction, resources and institutions, in: Journal of International Business Studies, $36,6,600-621$.

Michailova, S./Husted, K. (2003): Knowledge-sharing hostility in Russian firms, in: California Management Review, 45, 3, 59-77.

Minbaeva, D./Pedersen, T./Bjorkman, I./Fey, C.F./Park, H.J. (2003): MNC knowledge transfer, subsidiary absorptive capacity, and HRM, in: Journal of International Business Studies, 34, 6, 586-599.

Moeller, K./Svahn, S. (2004): Crossing east-west boundaries: knowledge sharing in intellectual business networks, in: Industrial Marketing Management, 3, 3, 219-228.

Mudambi, R. (2002): Knowledge management in multinational firms, in: Journal of International Management, 8, 1, 1-9.

Nelson, R./Winter, S. (1982): An evolutionary theory of economic change. Cambridge: Harvard University Press.

Nobel, R./Birkinshaw, J. (1998): Innovation in multinational corporations: control and communication patterns in international R\&D operations, in: Strategic Management Journal, 19, 5, 479-496.

Nonaka, I. (1994): Dynamic theory of organizational knowledge creation, Organization Science, 5, 1, 14-37.

Nonaka, I./Takeuchi, H. (1995): The knowledge creating company, New York, NY: Oxford University Press.

O'Dell, C./Grayson, J. (1998): If only we knew what we know: identification and transfer of internal best practice, California Management Review, 40, 3, 154-74.

Pearce, R./Tavares, A. (2000): Emerging trading blocks and their impact on the strategic evolution of multinationals, in: Managerial Finance, 23, 1, 26-40.

Penrose, E. (1959): The theory of the growth of the firm. New York: John Wiley.

Peteraft, M. (1993): The cornerstones of competitive advantage: A resource-based view, in: Strategic Management Journal, 14, 3, 179-191.

Polanyi, M. (1966): The tacit dimension. New York: Anchor Day.

Prahalad, C.K./Hamel, G. (1990): The core competence of the corporation, in: Harvard Business Review, 68, 3, 79-91.

Riege, A. (2005): Three dozen knowledge sharing barriers managers must consider, in: Journal of Knowledge Management, 9, 3, 18-35. 
Rugman, A. (1996): The theory of the multinational enterprise. Cheltenham: Edward Elgar.

Rugman, A./Verbeke, A. (2001): Subsidiary-specific advantages in multinational enterprises, in: Strategic Management Journal, 22, 3, 237-250.

Rumelt, R. (1984): Towards a strategic theory of the firm. Alternative theories of the firm, in: Lamp, R. (ed.): Competitive strategic management, Englewood Cliffs, NJ: Prentice Hall, 556-570.

Schmid, S. (2003): How multinational corporations can upgrade foreign subsidiaries: a case study from Central and Eastern Europe, in: Stüting, H.-J./ Dorow, W./Blazejewski, S./Claassen, F. (Eds): Change management in transition economies. Integrating corporate strategy, structure and culture, London: Palgrave Macmillan, 273-290.

Schmid, S./Schurig, A. (2003): The development of critical capabilities in foreign subsidiaries: Disentangling the role of the subsidiary's business network, in: International Business Review, 12, 4, 755-782.

Szulanski, G. (1996): Exploring internal stickiness: impediments to the transfer of the best practice within the firm, in: Strategic Management Journal, 17, 1, 27-43.

Szulanski, G. (2003): Sticky knowledge barriers to knowing in the firm, London: Sage Publications.

Taggart, J. (1998): Configuration and coordination at subsidiary level: foreign manufacturing affiliates in the UK, in: British Journal of Management, 9, 4, 327-339.

Tavares, A./Young, S. (2006): Sourcing patterns of foreign-owned multinational subsidiaries in Europe, in: Regional Studies, 40, 6, 583-599.

Teece, D./Pisano, G./Shuen, A. (1997): Dynamic capabilities and strategic management, in: Strategic Management Journal, 18, 7, 509-533.

UNCTAD (2011): World Investment Report 2011: Non-equity modes of international production and development, New York and Geneva: United Nations.

Wernerfelt, B. (1984): A resource-based view of the firm, in: Strategic Management Journal, $5,2,171-180$.

White, R./Poynter, T. (1984): Strategies for foreign-owned subsidiaries in Canada, Business Quarterly, 48, 4, 59-69.

Williams, D. (1998): The development of foreign-owned manufacturing subsidiaries: some empirical evidence, in: European Business Review, 98, 5, 282-286.

Williamson, O. (1999): Strategy research: Governance and competence perspectives, in: Strategic Management Journal, 20, 12, 1087-1110.

Zaheer, S. (1995): Overcoming the liability of foreignness, in: Academy of Management Journal, 38, 2, 341-363. 